[背景および目的] ゴマノハグサ科アゼトウガラシ属(Lindernia All.)に属するアメリカアゼナ(L.dubia Pennell)は、日本においては 2 タイプに区別できることが報告されている(森田，1994)。この 2 タイプは 葉の基部がそれぞれくさび形(connate)、円形(round)であることから、C タイプ・R タイプ、あるいは(狭 義の)ア归カアゼナ・タケトアゼナと区別されることが普通となっている。しかしながら、原産地の北米 での Pennell(1935)の記載以外、北米を含めた諸外国において、この 2 タイプを区別するような見解は 見当たらない。そこで、AFLP(Amplified Fragment Length Polymorphism)法による DNA-fingerprinting にて、日本における $L$. dubia が遺伝子レベルではどのような様相であるかを推定 し、分類階級を設けることへの妥当性を検討した。

[材料および方法] 供試材料および採集方法は表 1 に示す。アメリカアゼナとタケトアゼナは上記の方 法で葉の基部により同定した。アメリカアゼナ・タケトアゼナに対する対照として、アゼナ $(L$. procumbens)も供試した。1 集団あたり 3 個体(一部 1２ 個体)、葉あるいは地上部全体をディープフ リーザーにて保存した部位を用いた。DNAの抽出は Plant DNAzol (Invitrogen 社製)を用いて行われ た。制限酵素処理、ライゲーション、予備増幅および選択的増幅は AFLP analysis Core reagent kit (Invitrogen 社製)のプロトコールを一部改変した方法に従った。選択的増幅のプライマーは表 2 のと おりである。泳動はポリアクリルアミドにて行い、染色は銀染色キット(Promega 社製)を一部改変した方 法に従った。バンドは 100〜 500bp の範囲のものを目視にて読み取った。集団レベルのクラスター図は POPGENE 1.32 にて Nei(1978)の不偏遺伝距離を算出し、Clustering Calculator に入力することで作 成した。個体レベルのクラスター図は、Clustering Calculator の Sorensen Similarity(Dice Similarity)を 用いて作成し、ブーツストラップを実施した。また、Hickory 1.0 を用いて遺伝子多様度を算出した。

[結果および考察] 3 草種の集団ごとのクラスター図を作成したところ(図 1)、アゼナの全集団(pop1--) は、ア刈カアゼナ(pop2--)・タケトアゼナ(pop3--)から大きく離れて 1 つにまとまった。また、アメリカアゼ ナとタケトアゼナの集団もそれぞれまとまったが、不連続に分かれるかどうか判別できなかった。

そこで、アメリカアゼナおよびタケトアゼナの個体ごとのクラスター図を作成したところ(図 2)、ほとん どの個体がアメリカアゼナ(ind2---)とタケトアゼナ(ind3---)とに分離した。また、分離する境界(図中の 中央あたり)では、ブーツストラップにより 90\%以上の值を多く算出した。さらに、どのプライマーの多型 遺伝子座の割合についても(表 2)、アメリカアゼナ・タケトアゼナ間の值は、アメリカアゼナ内、タケトア ゼナ内およびアメリカアゼナ・タケトアゼナ合計よりも高い值を示した。これらのことから、アメリカアゼナ とタケトアゼナは、葉の基部の分類形質と一致して遺伝的にも区別できることが示唆された。ただし、 逆のまとまりに入っている個体(ind2032, ind2091)や両草種の中間に位置する個体(ind3103, ind3181, ind3183, ind3121)が少数みられ、このことからは、ア归カアゼナとタケトアゼナの交雑による中間的な タイプ、あるいは L. dubia のさらに別のタイプの可能性などが考えられるかもしれない。しかしながら、 これらの例外は少数であり、ほかの大部分は不連続に分離することから、分類階級を設ける意義は十 分にあると考えられる。その場合には、中間的な個体による遺伝子交流の可能性や遺伝距離、また形 態の相違や分類形質などを考慮すると、変種程度が適当ではないかと考えられる。

また、アゼナは在来種であり、アメリカアゼナとタケトアゼナはそれぞれ 1930 年代、1960 年代から確 認されている帰化草種であるが、多型遺伝子座の割合はアゼナが大きいものの(表 2)、今回の実験 からは、遺伝子多様度について帰化·定着年数との関係は見られなかった(表 3)。

Yoshino, N., G. -X. Wang and M. Ito: Does Lindernia dubia really have two types in Japan? verified by DNA-AFLP method. 
表1 日本産アゼトウガラシ風(Lindernia)の供試材料

\begin{tabular}{|c|c|c|c|c|c|}
\hline 草程 & 策団 ${ }^{a}$ & 揞生 & 由来 ${ }^{b}$ & 11ての & \\
\hline $\begin{array}{c}\text { アゼナ } \\
\text { L. orocumbens }\end{array}$ & 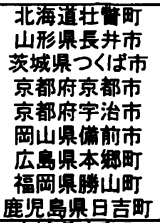 & $\begin{array}{l}\text { 水畐 } \\
\text { 休耕田 } \\
\text { 休耕田 } \\
\text { 水田 } \\
\text { 休耕田 } \\
\text { 娍反田 } \\
\text { 減反田 } \\
\text { 水田 } \\
\text { 水田 } \\
\end{array}$ & 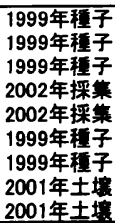 & $\begin{array}{l}\text { pop 101 } \\
\text { pop } 105 \\
\text { pop } 109 \\
\text { pop112 } \\
\text { pop113 } \\
\text { pop114 } \\
\text { pop115 } \\
\text { pop116 } \\
\text { pop119 }\end{array}$ & \\
\hline $\begin{array}{l}\text { アメリカアゼナ } \\
\text { L dubia C type }\end{array}$ & 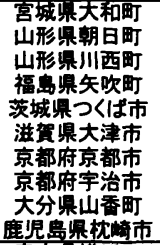 & $\begin{array}{l}\text { 娍反田 } \\
\text { 休耕田 } \\
\text { 休耕田 } \\
\text { アヤ冰田 } \\
\text { 休耕田 } \\
\text { 水田 } \\
\text { 水田 } \\
\text { 休耕田 } \\
\text { 水田 } \\
\text { 水田 }\end{array}$ & 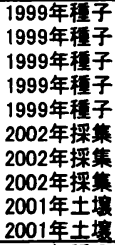 & $\begin{array}{l}\text { pop203 } \\
\text { pop206 } \\
\text { pop207 } \\
\text { pop208 } \\
\text { pop209 } \\
\text { pop211 } \\
\text { pop212 } \\
\text { pop213 } \\
\text { pop217 } \\
\text { pop218 }\end{array}$ & $\begin{array}{l}\text { ind203- } \\
\text { ind206- } \\
\text { ind207- } \\
\text { ind208- } \\
\text { ind209- } \\
\text { ind211- } \\
\text { ind212- } \\
\text { ind213- } \\
\text { ind217- } \\
\text { ind218- }\end{array}$ \\
\hline $\begin{array}{l}\text { タケトアゼナ } \\
\text { L dubia R type }\end{array}$ & 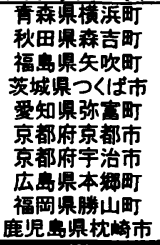 & $\begin{array}{l}\text { 減反田 } \\
\text { 娍反田 } \\
\text { 㶹田 } \\
\text { 休耕田 } \\
\text { 娍反田 } \\
\text { 水田 } \\
\text { 休耕田 } \\
\text { 娍反田 } \\
\text { 水田 } \\
\text { 水田 }\end{array}$ & 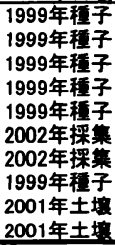 & $\begin{array}{l}\text { pop302 } \\
\text { pop304 } \\
\text { pop308 } \\
\text { pop309 } \\
\text { pop310 } \\
\text { pop312 } \\
\text { pop313 } \\
\text { pop315 } \\
\text { pop316 } \\
\text { pop318 }\end{array}$ & $\begin{array}{l}\text { ind302- } \\
\text { ind304- } \\
\text { ind } 308- \\
\text { ind309- } \\
\text { ind310- } \\
\text { ind312- } \\
\text { ind313- } \\
\text { ind315- } \\
\text { ind316- } \\
\text { ind318- }\end{array}$ \\
\hline & & & & & \\
\hline
\end{tabular}

表2 プライマーことの多型バンド数および多型逗伝子座の割合(P/)

\begin{tabular}{|c|c|c|c|c|c|c|c|c|}
\hline \multirow[b]{2}{*}{$\begin{array}{c}\text { 草種の組み } \\
\text { 合わせ }\end{array}$} & \multicolumn{6}{|c|}{ ブライマーの組み合わせ(EcoRI/Msel) } & \multicolumn{2}{|c|}{ Total } \\
\hline & $\begin{array}{l}\text { 型型 } \\
\text { 代义 } \\
\text { ド数 }\end{array}$ & $\begin{array}{l}P I \\
(x) \\
\end{array}$ & $\begin{array}{l}\text { 桨型 } \\
\text { ハジ } \\
\text { ド數 }\end{array}$ & $\begin{array}{l}P l \\
(\boldsymbol{*}) \\
\end{array}$ & $\begin{array}{l}\text { 型 } \\
\text { 代 } \\
\text { ド数 }\end{array}$ & $\begin{array}{l}P I \\
(\%)\end{array}$ & $\begin{array}{c}\text { 多型 } \\
\text { パンド } \\
\text { 数 }\end{array}$ & $\begin{array}{l}P I \\
(\%)\end{array}$ \\
\hline アゼナ内 & 9.7 & 25.4 & 7.1 & 31.6 & 3.8 & 13.5 & 21.2 & 24.0 \\
\hline ア帅カアゼナ内 & 5.7 & 26.5 & 3.5 & 19.7 & 5.8 & 13.0 & 15.1 & 18.8 \\
\hline タケトアゼナ内 & 4.6 & 22.7 & 5.7 & 25.2 & 8.5 & 18.1 & 18.2 & 21.2 \\
\hline $\begin{array}{l}\text { ア归かアセ゚ナ・タ } \\
\text { ケトアゼ間 }\end{array}$ & 7.6 & 34.8 & 12.1 & 52.1 & 22.2 & 44.7 & 41.5 & 45.1 \\
\hline $\begin{array}{l}\text { ア邚カアセナ・タ } \\
\text { ケトアゼナ合計 }\end{array}$ & 6.4 & 29.8 & 8.4 & 37.4 & 14.8 & 30.3 & 29.1 & 32.6 \\
\hline $\begin{array}{l}\text { アセナ・林汃 } \\
\text { セ゚間 }\end{array}$ & 39.7 & 88.2 & 31.8 & 99.1 & 54.3 & 91.9 & 124.1 & 92.2 \\
\hline $\begin{array}{l}\text { アセナ・タskア } \\
\text { †間 }\end{array}$ & 40.5 & 89.4 & 33.7 & 95.4 & 51.3 & 90.3 & 124.3 & 91.1 \\
\hline 合㖕 & 20.5 & 53.8 & 19.0 & 63.3 & 30.7 & 55.9 & 68.1 & 56.6 \\
\hline
\end{tabular}

\section{表3 各草種内の全集団の遗伝子多様度 $\left(H_{T}\right)$}

\begin{tabular}{|c|c|}
\hline & $H_{T}$ \\
\hline $\begin{array}{l}\text { アゼナ } \\
\text { アメリカアゼナ } \\
\text { タケトアゼナ } \\
\text { アメリカアゼナ.タケトアゼナ合計 }\end{array}$ & $\begin{array}{ll}0.2252 & (0.0094) \\
0.1886 & (0.0053) \\
0.2200 & (0.0068) \\
0.1964 & (0.0046) \\
\end{array}$ \\
\hline
\end{tabular}

\section{2年採葉: 同年に直接フィールドにて探葉}

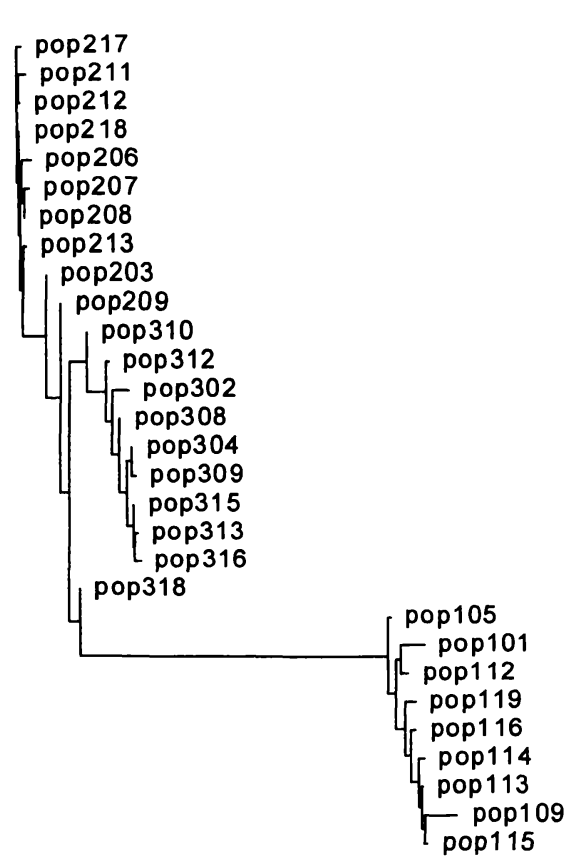

0.1

図1 日本におけるアゼナ(pop1--)、アメリカ アゼナ(pop2--)およびタケトアゼナ(pop3--) の集団ごとのクラスター図。NJ法により作 成。バーはNei(1978)の不偏遗伝距離を示 す。

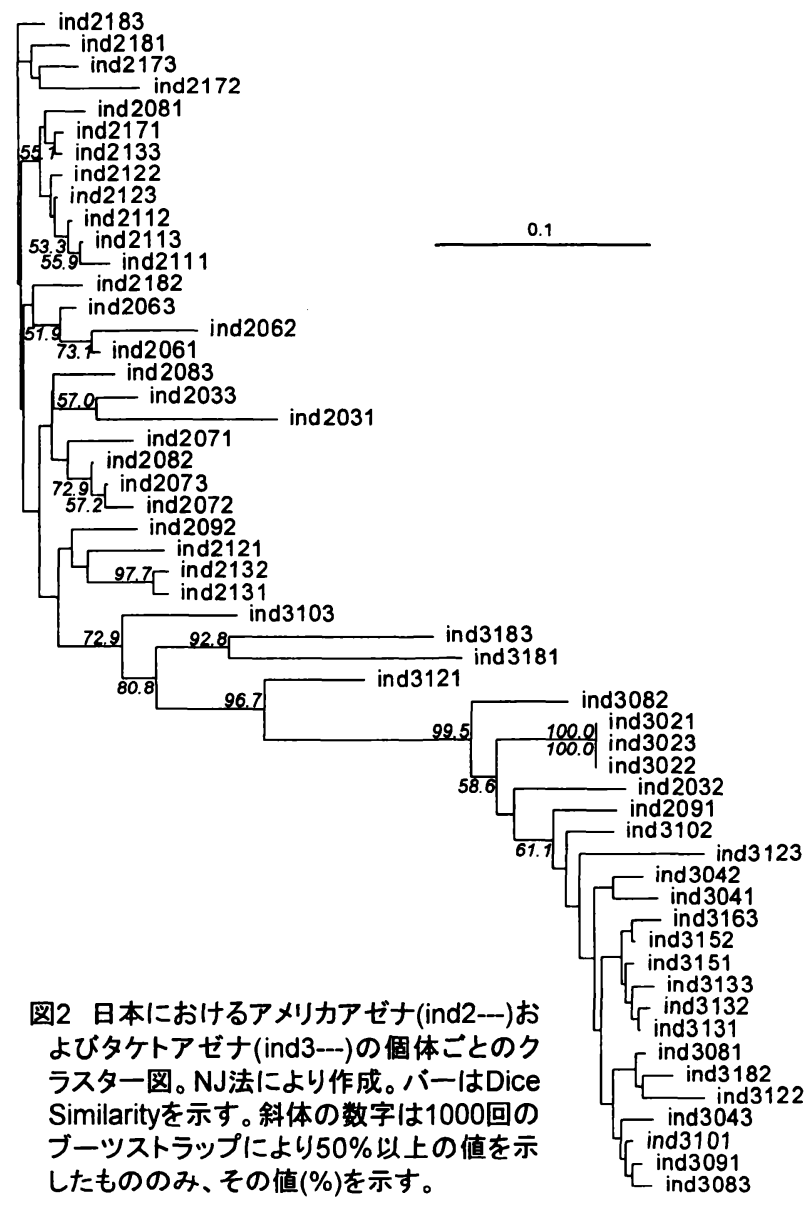

